\title{
Fortified masserie in Calabria. Architectural features and typological models
}

\author{
Daniele Colistra $^{a}$, Domenico Mediati ${ }^{b}$ \\ Università degli Studi Mediterranea, Reggio Calabria, Italy \\ adaniele.colistra@unirc.it; ${ }^{\mathrm{b}}$ domenico.mediati@unirc.it
}

\begin{abstract}
In Southern Italy, and also in Calabria, fortified masserie represent a typical building model meant for the management, the control and the defense of the territory and of the rural heritage. This occurs especially in areas where, before the agricultural reform of the mid-twentieth century, the latifundium was the main model of property organization. The geographical position of the region, which has always been exposed to incursions and looting, has favored, in the rural buildings, the presence of defensive morpho-structural elements and above all the spread of typological plants that make the building system closed to the outside and therefore protected. This is the main topic of the research. Through the study, survey and analysis of 26 fortified masserie on the Calabrian territory, we have identified three particularly widespread typologicalsettlement models: the fortress masseria, the court masseria, the block masseria.
\end{abstract}

Keywords: fortified masseria, Calabria, defense architectures.

\section{The Latifundium and the Agrarian Revolts}

Between the fifteenth and sixteenth centuries, in Calabria, the feudal system of landowners was still dominant, but the economic crisis that affected the region between 1582 and 1595 triggered processes of destabilization. The peasants began to claim their rights, clashing with the lords' resistance. This resulted in a tightening of feudal relations, an inevitable worsening of social tensions and a growing insecurity of the land heritage. The spontaneous revolts became more and more widespread, turning into brigandage that involved large masses of peasants (Colistra, Mediati, 2011, pp. 122-123).

The plague epidemic that occurred around the middle of the seventeenth century aggravated an already extremely difficult situation. The intensification of demographic decline increased the phenomenon of rural depopulation and raised the degradation of the entire area (Milella, 1992, p.
32). In such an unstable context, in the northeast of Calabria, numerous masserie with fortification elements or with obvious closing characteristics with respect to the surrounding context arose. They were added to those already existing defining a much denser agricultural landscape compared to other areas of the region.

\section{Characteristics of Fortified Masserie in Ca- labria}

Before addressing the topic, an etymological clarification is required. The term "masseria", in fact, is often not clearly defined (Greppi, 1970, p. 387), and even the "fortified" attribute can be interpreted with different and sometimes opposite meanings. Referring to the in situ research by Benito Spano (1970, pp. 271-290), we have chosen the following definition of "masseria" in the specific Calabrian context: "The masseria 
consists of a system of several rural buildings, closely related to each other (even if not contiguous), destined to the agricultural exploitation of the annexed land, to the processing of agricultural products, to the storage of foodstuffs, to the shelter of livestock and to the residence of the people who work there".

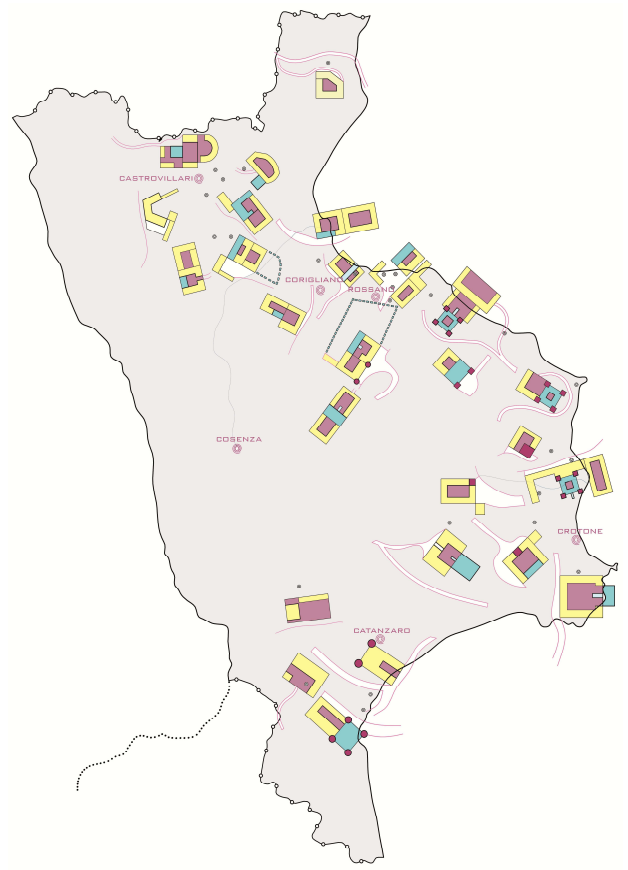

Fig. 1. Ideogrammatic scheme of fortified masserie in north-western Calabria.

In the present research, the notion of fortification has been referred not only to the morphological and structural parts of the building built for defense (drains, loopholes, bretèches, crossbowmen, bastions, battlements and, in general, all defensive elements), but also to a precise morphological and typological condition that makes the building clearly "closed" to the outside. This definition has allowed us to overcome the problems developed by some authors, who consider fortification as a condition common to all historical rural buildings and which, therefore, cannot be taken as a classification category.

Given these premises, with specific reference to the Calabrian territory, we considered that in order for a masseria to be considered "fortified", the following conditions must exist simultaneously (Colistra \& Mediati, 2011, pp. 13-14):

- the masseria must be located in a rural context;

- the masseria must be used for the management of an agricultural plot, adjacent to it;

- the masseria must have specific buildings for different activities (residence, deposit, work, animal shelter, socialization, worship, etc.). In particular, there must also be a clear difference between the homes of those who live permanently (feudatory, farmer, permanent and seasonal workers, etc.);

- the masseria must be equipped with defense structures;

- the masseria must have a closed internal space in which, in cases of emergency, it is possible to carry out activities commonly performed outside. For this reason, the fortified masseria always has a closed court or a continuous fence;

- the masseria must not have windows open to the outside on the ground floor; more precisely, the windows may be present, but of minimum dimensions and equipped with railings.

Furthermore, there are elements that we did not consider indispensable for this type of construction but which recur frequently and, therefore, are typical. Among these:

- a gatehouse, usually located on the main entrance, to check arrivals and internal activities of the court;

- a stylistically more refined entrance, often arched and with a portico;

- a main house that recalls the characteristics of the urban palace or the country villa;

- a well or cistern, inside the court;

- fortification elements on the corners of the architectural structure (with a square, polygonal, circular plan);

- a chapel for worship, often external to the system or with an entrance open to the outside.

\section{Three Typological Models for Defense}

In the initial phase of the research, we carried out a study that allowed us to draw up a list of 
584 rural buildings in the region, whose morphological and typological characteristics could have been traced to the definition of a fortified masseria. We have created a summary of each building, based on bibliographic sources and provided with graphic and photographic references. This cataloging allowed us to understand the recurrent characteristics of the historical rural building heritage in Calabria. Of all the 584 buildings initially studied, 98 were considered congruent with the definition of "fortified masseria" and were the subject of the next phase of the research, based on site inspections. At the end of this phase, we found that many of the 98 masserie considered did not exactly correspond to the definition of "fortified masseria" because they lacked some of the characteristics that define it. The Calabrian fortified masserie that we have considered are 26 , located mainly on the Ionian coast of the Cosenza and Crotone area.

The following phase was dedicated to the definitive compilation of the detailed forms, which allowed us to identify three main typological categories: the fortress masseria, the block masseria, court masseria.

Identifying and defining categories -in particular for such complex building systems- inevitably involves a drastic simplification of their architectural characteristics. The categories, in fact, should be as many as the examples taken into consideration, because each of them presents characteristics of uniqueness that distinguish it from all others; nor is it conceivable that exist (or have existed) rigorous reference models for the construction of buildings so different in terms of layout, size and time of construction.

The fortress masseria (nine cases analyzed) consists of a building that corresponds to a typically defensive typological model, or that develops incorporating an existing building built with precise defensive needs: a castle (Solano, Messanelli, Sabatini, Venneri), a tower (Massara, Torre di Fasana, Torre Pinta), a fortified casino (Pepe, Monisciano). In most cases, a fortified building is flanked by other buildings more or less equipped with defensive structures.

The block masseria (eight cases analyzed) is generated by aggregation of different elements, not always responding to an accomplished design but able to obtain, favored by their position, a closed unitary space attributable to the definition of court. The court is obtained from the presence of a linear element, the enclosure (San Mauro, Gonzales, Migliuso); or from the aggregation of different building volumes (Parapugna, Gallo, Camporota), which sometimes nterrupt the continuity of the enclosure forming a mixtilinear set of buildings that align with the perimeter wall (Varcasia, Tamburi).
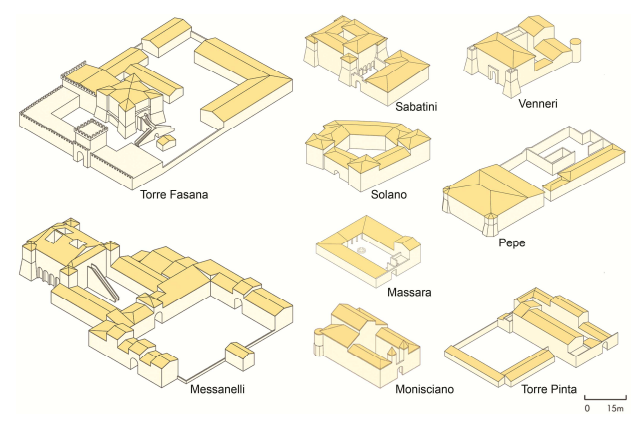

Fig. 2. Fortress masserie.

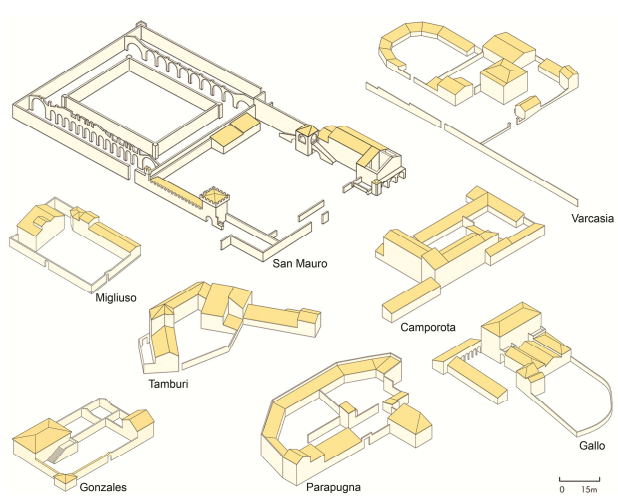

Fig. 3. Block masserie.

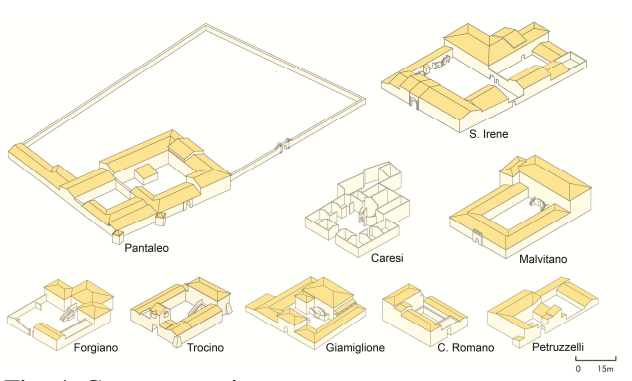

Fig. 4. Court masserie. 


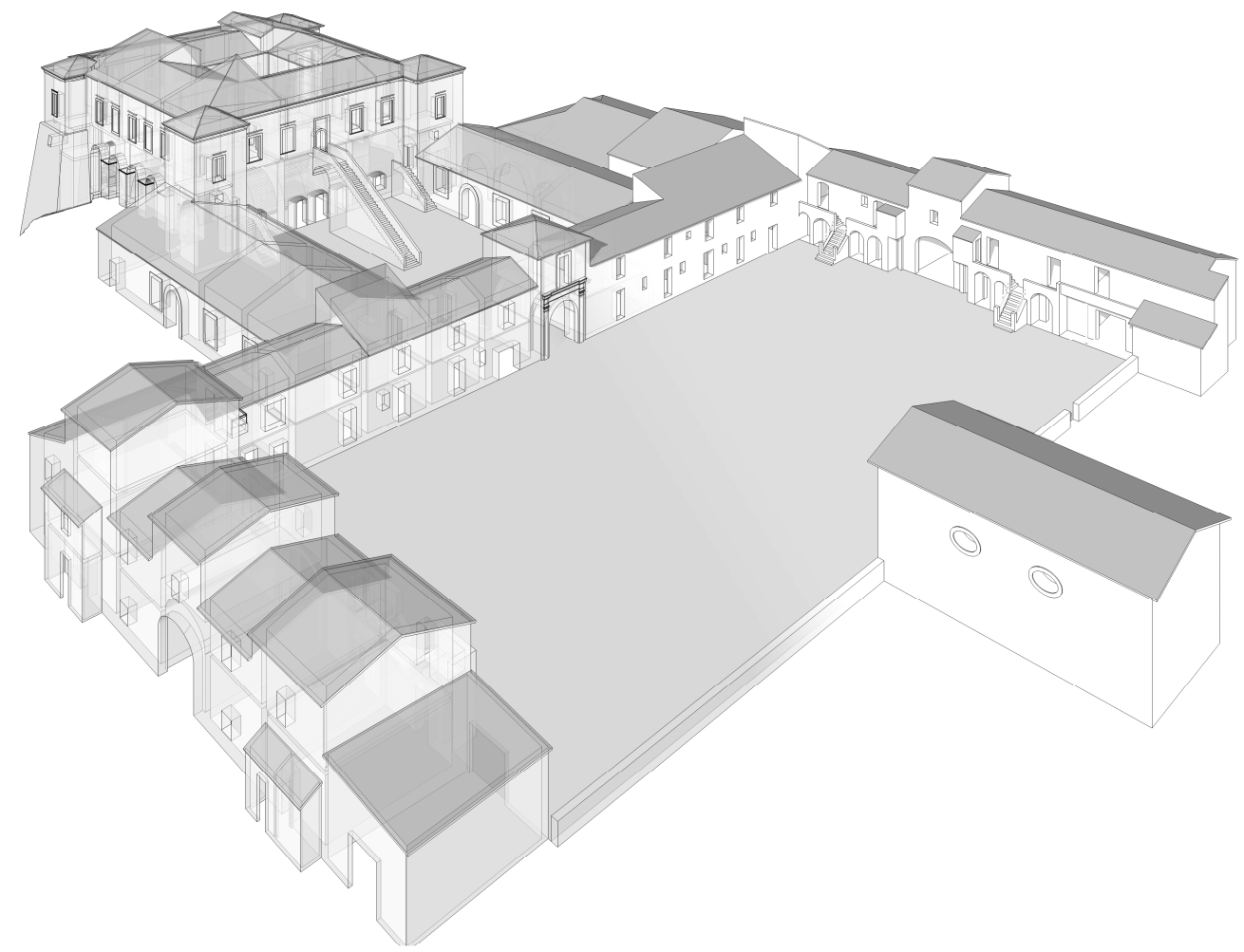

Fig. 5. Masseria Messanelli, Mirto Crosia.

The court masseria (nine cases analyzed) corresponds to the classic typological model in which a continuous volume circumscribes one or more interior spaces, with a mainly regular shape. In some cases these are structures built according to a unified and formally completed design (Giamiglione, Caresi, Forgiano); in other cases, the overall volume derives from the summation of several elements (often realized in different periods) but which, as a whole, generate a homogeneous architectural space (Petruzzelli, Malvitano, Sant'Irene, Casello Romano, Trocino); finally, in only one case, the masseria consists of a building with a double court from which a boundary wall starts which encloses a large portion of territory (Pantaleo).

\section{Masseria Messanelli: the Fortress Masseria}

Between the fifteenth and sixteenth centuries, a typology of masseria that later would become particular to the area spread in north-eastern Calabria it generally stood at the far end of a rise, to protect a valley or the coastal strip. This is the case of Masseria Messanelli in Crosia, built at the beginning of the sixteenth century and then enlarged around 1750 . Its function was managing the important agricultural activities of the Mandatoriccio baronial fiefdom.

The structure is extremely complex. The main building, with a square plan, corner towers and internal court, constitutes the original nucleus. Subsequently, two large courts and a series of buildings were added to the native structure. The central block, located to the west, has a small inner court and is on two floors, which become three towards the overhanging. The eastern front opens onto a further court, dominated by a single straight ramp that leads to the manor house. 


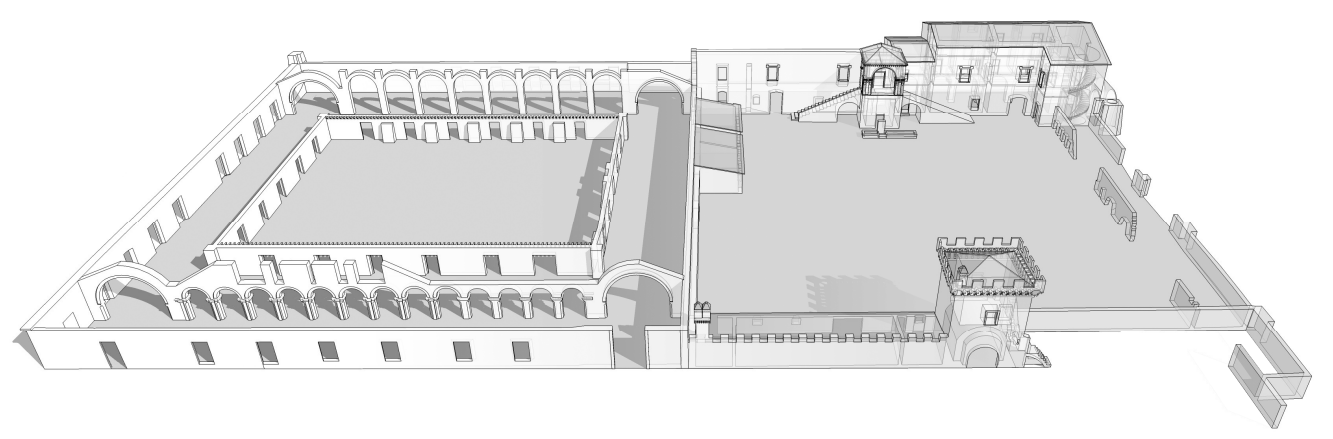

Fig. 6. Masseria San Mauro, Corigliano Calabro.

On the ground floor there are warehouses and other service areas. There is also a further very large court which is accessed via two underpasses located on the northern and southern sides. It is enclosed, to the east, by a thin wall, interrupted on the middle by a chapel.

The obvious defensive elements of the original core gave the building the hardness of a fortified system. The initial defense requirements, however, gradually gave way to more relaxed relations with the peasantry, as evidenced by the formally less hostile character of the subsequent expansion interventions.

\section{Masseria San Mauro: the Block Masseria}

The Masseria San Mauro in Cantinella of Corigliano was built in $1515^{1}$ and presents a block typological scheme. It was the country residence of the Sanseverino family, princes of Bisignano, and fulfilled the task of sorting and collecting agricultural products. The vast building, now abandoned, is located in the Piana di Sibari, at the foot of the Greek Sila. It has two buildings side by side, on which some defensive elements are evident: boundary walls adorned with battlements, buttresses, loopholes, machicolations.

The overall building is rectangular, with two adjoining courts. The watch tower is the element with the most evident fortifying features: crenellated crowning with machicolations and look out location with loopholes that flanks the access gate. However, its fortifying elements seem more like an ornament than actual instruments of armed resistance.
The portal leads to a first court. On its northern side there is a two-storey building. It has a double ramp staircase that, through a loggia, leads to the main house. It expresses the character of a noble palace, far from the grim appearance of a fortress. On its right there are the remains of a large cistern. On the western side there is a second quadrangular court which, with a system of round arches, recalls the image of a conventual cloister ${ }^{1}$.

The Masseria San Mauro does not look strong and impregnable. It shows an austere kindness and seems more suited to resisting attacks with medieval weapons rather than arresting the fire of modern artillery of regular armies. In fact, the fortification elements are proportionate to the need to resist exclusively the attacks of agrarian banditry, which did not have warfare tools and techniques that required particularly advanced defensive structures.

\section{Masseria Forgiano: the Court Masseria}

Often in the Calabrian masserie the fortifying elements are even less evident. The presence of a perimeter wall and a planimetric conformation closed towards the outside are sufficient precautions for the protection of men and goods.

An example is the Masseria Forgiano in Isola Capo Rizzuto, a quadrilateral plant with a closed court. It has a two-storey building, located to the north, with a central block set back, on which two symmetrical wings are grafted. On the eastern side of the court there is a single-storey building with service areas. On the southern front, a small two-storey body that flanks the 

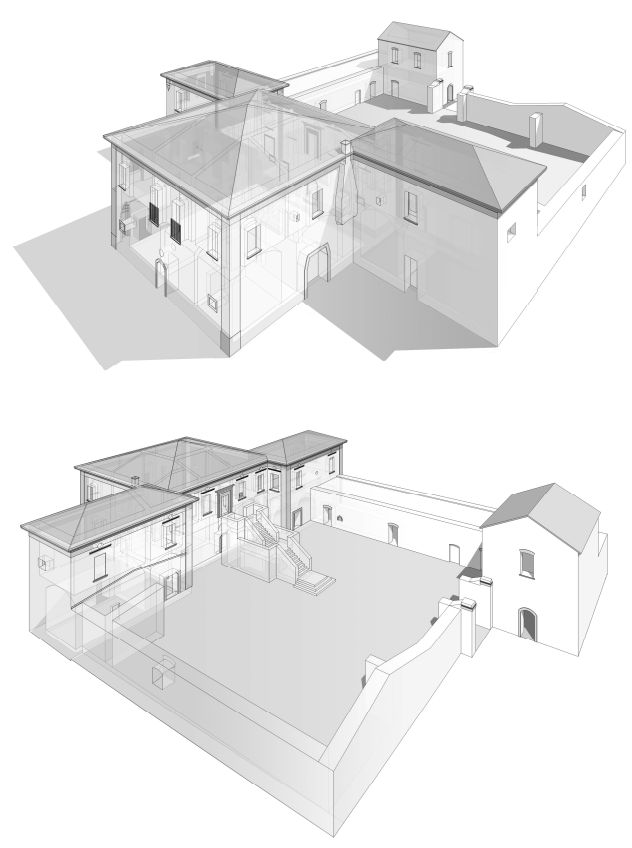

Fig. 7. Masseria Forgiano, Isola Capo Rizzuto.

entrance joins it. The rest of the perimeter of the court is completed by a boundary wall. Due to its conformation, it reveals the ancient presence, on the western side, of a further single-storey building, now completely ruined. The main building has a double purpose: service rooms on the ground floor and residence on the upper floor. It was accessed via a scenic staircase that dominated the court. In the side buildings, of which only the eastern part remains, there were the mill, the stables and the residences for the wage earners.

The residential block looks like a noble palace in which the shrewdness of not opening wide openings on the external walls is not even adopted. The closed court is the only element of passive defense, but it is also the place of collective relationships, the place of contact between lords and peasants, the place of eventual exchange relations. The court recalls the classic concept of agora, of the market square, around which the spaces of production and conservation are organized (Tommaselli, 1986, p. 96).

\section{The Court and the Boundary}

Starting from the second half of the sixteenth century, in the treatises and in the operative practice, there is a progressive separation between civil and military architecture (Messina, 2003, p. 593). In Calabria, vice versa, a reverse process takes place. In fact, the particular economic and social conditions push towards an integration of these two aspects of building. The masseria is not just a building with a productive function. It requires adequate typological choices for the protection of men and goods. However, the elements of defense are not flaunted but they integrate with formal and typological needs. The recurring element is the construction of a perimeter: the separation, the boundary between inside and outside. A sort of margin that marks the border between "city and countryside", between places of exchange and places of production (Pirajno, 1989, p. 78). Even after overcoming the conflict between the nobility and agrarian banditry, when the danger passes, the defensive characteristics and closure to the outside will continue to persist. They will lose their defensive function and will adapt to productive needs, but they will remain as a reminiscence and testimony of a social change (Pagano, Guarniero, 1936, p. 27).

\section{Notes}

${ }^{1}$ Following the archaeological excavations of 1969 , it was assumed that the masseria was built on the ruins of a medieval building, perhaps a monastery (Quilici, et al., 1969, p. 142).

${ }^{2}$ Elio Manzi maintains that the masseria joins a previous monastery and with it forms a single body with two courts (Manzi, Ruggiero, 1987).

* This research is the result of a common work; in this essay, paragraphs 2 and 3 are written by Daniele Colistra, paragraphs 1, 4, 5, 6 and 7 by Domenico Mediati. 


\section{Bibliography}

Colistra, D.; Mediati, D. (2011). Masserie fortificate in Calabria, liriti Ed., Reggio Calabria.

Greppi, C. (1970). "Evoluzione dei modelli della casa rurale", in Barbieri G., Gambi L. eds., La casa rurale in Italia, Leo S. Olschki Ed., Firenze, pp. 383-402.

Manzi E.; Ruggiero, V. (1987). La casa rurale nella Calabria, Olschki Ed. Firenze.

Messina, B. (2003). "La città fortificata: geometria e forma", in Il disegno della città. Opera aperta nel tempo, Atti del Convegno Internazionale di San Gimignano 28-30 giugno 2002, Alinea Ed., Firenze, tom. I, pp. 593-596.

Milella, O. (1992). Torri e masserie nel "giardino mediterraneo", Gangemi Ed., Roma.

Pagano, G.; Guarniero, D. (1936). Architettura Rurale italiana, in Quaderni della Triennale, Hoepli Ed., Milano.

Pirajno, R. (1989). "Dalla città al territorio; l'architettura del margine", in AA.VV., Matrici e permanenze di culture egemoni nell'architettura del bacino del Mediterraneo, Flaccovio Ed., Palermo, pp. 75-108.

Quilici, L.; et al. (1969). Carta archeologica della Piana di Sibari, in Atti e Memorie della Società Magna Grecia, Nuova Serie IX-X (1968-1969), Roma.

Spano, B. (1970) "La masseria meridionale”, in Barbieri, G.; Gambi, L. eds., La casa rurale in Italia, Leo S. Olschki Ed., Firenze, pp. 271-290.

Tommaselli, M. eds. (1986). Masserie fortificate del Materano, Cassa di risparmio di Calabria e Lucania, De Luca Ed., Roma. 
